\title{
Development of a qPCR Protocol to Detect the Cotton Bacterial Blight Pathogen, Xanthomonas citri pv. malvacearum, from Cotton Leaves and Seeds
}

\begin{abstract}
Xiao-Qiang Wang, Department of Biochemistry, Molecular Biology, Entomology and Plant Pathology, Mississippi State University, Mississippi State, MS, U.S.A.; and Pest Integrated Management Key Laboratory of China Tobacco, Tobacco Research Institute of Chinese Academy of Agricultural Sciences, Qingdao 266101, China; Tom W. Allen, Delta Research and Extension Center, Mississippi State University, Stoneville, MS, U.S.A.; Hui Wang and Daniel G. Peterson, The Institute for Genomics, Biocomputing \& Biotechnology, Mississippi State University, Mississippi State, MS, U.S.A.; Robert L. Nichols, Cotton Incorporated, Cary, NC, U.S.A.; Aixin Liu and Xiang-Dong Li, Department of Plant Pathology, College of Plant Protection, Shandong Agricultural University, Taian, Shandong, China; Peng Deng, David Jia, and ShiEn Lu, ${ }^{\dagger}$ Department of Biochemistry, Molecular Biology, Entomology and Plant Pathology, Mississippi State University, Mississippi State, MS, U.S.A.
\end{abstract}

\begin{abstract}
Bacterial blight, historically a seed-borne disease of cotton (Gossypium hirsutum) is caused by Xanthomonas citri pv. malvacearum, resulted in significant economic losses prior to development of resistant varieties and implementation of acid-delinting of planting seed. Periodic outbreaks have been associated with seed since the early twentieth century; of note, the disease has experienced a resurgence since 2011. Effective management of bacterial blight is dependent on accurate diagnosis and detection of the pathogen. Currently, detection of $X$. citri pv. malvacearum is performed by time-consuming microbiological methods. In this study, a novel and sensitive TaqMan-based qPCR protocol was developed to test for $X$. citri pv. malvacearum in cotton plant tissue. The primers developed are specific

to five races of $X$. citri pv. malvacearum, but not to other Xanthomonas species or cotton-associated nonpathogenic bacteria. The efficiency of this assay was evaluated on artificially inoculated cotton leaves and seed, on naturally infected cotton leaves, and on bolls and seed originating from bacterial blight symptomatic bolls. The protocol's efficiency from artificially inoculated plant tissue was $10^{2}$ copies $\mathrm{g}^{-1}$ and 37 copies from $1 \mathrm{~g}$ seed for leaves and seed, respectively. In addition, X. citri pv. malvacearum was detected from $94 \%$ of the seed samples originating from blight symptomatic bolls. The qPCR protocol provides a rapid and accurate method for diagnosis and detection of bacterial blight and offers a tool for monitoring $X$. citri pv. malvacearum and potentially reducing its spread in seed.
\end{abstract}

The genus Xanthomonas is notable in its phytopathogenic diversity and phenotypic uniformity (Starr 1981; Vauterin et al. 2000). Due to its economic importance, Xanthomonas has been the subject of several large-scale taxonomic (Ah-You et al. 2009; Vauterin et al. 2000; Yang et al. 1993) and pathogenesis studies (De Feyter et al. 1993; Lee et al. 2005). In addition, over the past several years, careful attention has been directed to the identification and nomenclature of species within the genus (Vauterin et al. 1995; Young et al. 2008). Numerous important pathogens are classified within the genus Xanthomonas. In fact, most economic crops are affected by at least one species of Xanthomonas.

Xanthomonas citri is the most heterogeneous species within the genus (Brunings and Gabriel 2003; Graham et al. 2004). Names within the citri group generally include a post-species epithet indicating the pathovar (pv.) designation that indicates the strain causing disease in a particular host plant. Several important diseases are caused by members of the citri group, including bacterial canker of citrus (Citrus spp.; caused by X. citri pv. citri), bacterial pustule of soybean (Glycine max (L.) Merr.; caused by X. citri pv. glycines), and bacterial blight of cotton (Gossypium hirsutum L.; caused by $X$. citri pv. malvacearum) (Ah-You et al. 2009; Kemerait et al. 2017; Phillips et al. 2017). Bacterial blight of cotton, also referred to as seedling blight, angular leaf spot, vein blight, black arm, and

${ }^{\dagger}$ Corresponding author: S.-E. Lu; E-mail: s1332@msstate.edu

Funding: This research was supported by a cooperative research agreement from Cotton Incorporated (grant no. 13-763) and by the U.S. Department of Agriculture (USDA) National Institute of Food and Agriculture (grant no. MIS-401170).

*The $\boldsymbol{e}$-Xtra logo stands for "electronic extra" and indicates that five supplementary figures are published online.

Accepted for publication 27 August 2018.

@ 2019 The American Phytopathological Society bacterial boll rot, was first reported in Alabama in 1891 and initially referred to as black rust (Atkinson 1891). Bacterial blight of cotton can result in the production of characteristic, angular, water-soaked lesions on leaves (Innes 1983; Thaxton and El-Zik 2001; Verma 1986). Bacterial blight can also be responsible for the production of lesions on all cotton plant parts from cotyledon-stage cotton to adult plants including the fruit or boll that encloses the seed. Severe bacterial blight infection can result in premature defoliation and boll shed, resulting in yield losses (Jalloul et al. 2015; Schaad et al. 2006). Historically, bacterial blight of cotton has been a major cotton disease producing substantial yield losses, ranging from 10 to $77 \%$ in susceptible cultivars during periods of severe epidemics (Hillocks 1992; Razaghi et al. 2012; Thaxton and El-Zik 2001; Umesha et al. 2010). In the United States, bacterial blight tends to appear in fairly geographically narrow regions. The disease does occur in parts of Oklahoma and Texas, and more recently epidemics have occurred in the mid-southern and southeastern regions of the United States (Kemerait et al. 2017; Phillips et al. 2017; Rothrock et al. 2012). When growing cotton is not in the field, $X$. citri pv. malvacearum has the ability to overwinter on cotton plant residue for short periods (months) and in seed cotton and lint for more extended periods (years) (Davis and Sandidge 1977; Verma 1986). However, the reported cases of long-term survival have all been in environmentally protected, indoor locations, for example, in the laboratory and at cotton gins (Davis and Sandidge 1977; Innes 1983; Mehta et al. 2005; Thaxton and El-Zik 2001; Verma 1986). Moreover, X. citri pv. malvacearum survives poorly in soil without the presence of infected plant residue (Massey 1930), and has been reported to have a shorter survival period in moist than in dry soil (Brinkerhoff and Fink 1964). Tillage is one form of management, since $X$. citri pv. malvacearum is a poor competitor with other soil-borne organisms (Thaxton and ElZik 2001; Verma 1986). Even though the bacterium can survive between seasons in dried field debris, the primary means of transmission remains infected/infested seed (Innes 1983; Thaxton and ElZik 2001; Verma 1986).

Seed is widely reported to be the primary source of inoculum for the initiation of bacterial blight in cotton fields (Brinkerhoff and 
Hunter 1963; Innes 1983; Schnathorst 1964; Thaxton and El-Zik 2001; Verma 1986). The infection rates of cottonseed with $X$. citri pv. malvacearum has previously been reported to range from $<1 \%$ to between 10 and 20\% (Archibald 1927; Bain 1939; Chester 1938; Rolfs 1915; Schnathorst 1968). Bacterial blight can be destructive even where only a single infected plant per 6,000 plants is observed (Hillocks 1992; Tarr 1961). One symptomatic plant can serve as a source for the pathogen to move throughout a field by local dissemination under favorable environmental conditions and via mechanisms that include wind-driven rain and agricultural equipment (Brown 1942; Davis and Sandidge 1977; King and Brinkerhoff 1949; Verma 1986). Long-range movement of the bacterium $(>3.2 \mathrm{~km}$ ) has not been reported (Brown 1942; Massey 1929).

Bacterial blight was largely eliminated in the United States following the general adoption of acid-delinting of cotton seed in the 1970s. Acid-delinting removes the cotton lint from the seed coat, thus eliminating a prime tissue that supports bacterial survival. Acid-delinting also tends to remove less dense seed from seed lots; such seeds may be harboring the bacterium within the embryo (Cherry and Leffler 1984; Delouche 1986; Innes 1983). Nonetheless, acid-delinting does not completely eradicate the organism from seed since internal seed infection does occur (Brinkerhoff and Hunter 1963; Schnathorst 1964, 1968). Reports of detection of X. citri pv. malvacearum following acid-delinting indicate the organism may still be present at low frequencies $(\approx 0.1$ to $1 \%$ ) (Alexander et al. 2012; Bain 1939; Rothrock et al. 2012; Schnathorst 1968).

Planting pathogen-free seed is an important first step to reduce the incidence and impact of bacterial blight. However, current methods of detecting $X$. citri pv. malvacearum from cotton planting seed and for screening seed are extremely laborious and outdated (Heintz 1997). In the past, efforts to develop a method to detect specific species within the genus Xanthomonas from seed was unsuccessful due to the high degree of specificity required to detect certain genotypes among the pathovars. To date, detection of $X$. citri pv. malvacearum from cottonseed is based on time-consuming microbiological methods to recover the microorganism. Such methods rely on nonspecific microbiological media and identification of colony morphology followed by, in some cases, plant inoculation to verify pathogenicity of the bacteria isolated (Brinkerhoff and Hunter 1963; Hunter and Brinkerhoff 1964; Rothrock et al. 2012; Schnathorst 1968). Specific serological techniques to detect bacteria from seed have been developed in other plant systems, but not for cotton. The presently available enzyme-linked immuno-sorbent assays (ELISA) that use antibodies against species of Xanthomonas lack the ability to distinguish between different pathovars within distinct subgroups. One non-ELISA method was developed to detect the carrot (Daucus carota subsp. sativus (Hoffm.) Schübl. \& G. Martens) bacterial leaf blight bacterium ( $X$. citri pv. carotae) from seed using PCR primers that were developed based on random amplified polymorphic DNA (RAPD) analysis (Meng et al. 2004). The reproducibility and timeefficiency of quantitative, real-time PCR presents the possibility of assaying seed-borne pathogens rapidly and accurately (Gitaitis and Walcott 2008). Following the widespread outbreaks of bacterial blight of cotton in the mid-southern United States in 2011, multiple microbiological methods were serially combined to detect $X$. citri $\mathrm{pv}$. malvacearum from 34 potentially infected cotton seed lots (Rothrock et al. 2012). The combined methods, while being able to positively identify $X$. citri pv. malvacearum, required substantial time and included several labor-intensive seed washings for each seed lot followed by morphological identification of $X$. citri pv. malvacearum in vitro and confirmation of pathogenicity in planta.

A sensitive method to detect $X$. citri pv. malvacearum in seed requires the specificity to discriminate among the races. Races of $X$. citri pv. malvacearum tend to be geographically distinct and incite disease in specific cotton producing areas (AbdelRahim et al. 2013; Abdo-Hasan et al. 2008). Twenty-two races of X. citri pv. malvacearum have been described (Hillocks 1992; Jalloul et al. 2015; Phillips et al. 2017). Race 18 is the one most frequently encountered in the United States. To date races 20, 21, and 22 have been reported only from Central Africa (Abdo-Hasan et al. 2008; Allen and West 1991; Baldwin and Wrather 1973; Hunter et al. 1968; Hussain 1984; Jalloul et al. 2015; Thaxton and El-Zik 2001; Verma et al. 1975). To avoid false positives, a method to detect $X$. citri pv. malvacearum in cotton needs to discriminate it from multiple species of Xanthomonas (Heintz 1997; Heintz and Akinwunmi 1997).

Development of a rapid and accurate procedure for detection of $X$. citri pv. malvacearum from cottonseed, as well as field-infected cotton plant tissue, can potentially be helpful to mitigate the damage and limit the spread of the disease. In the field, a light infestation of bacterial blight may go unnoticed. The current procedures used to scout fields for seed production are based on the presence of disease symptoms on plant material, oftentimes at the end of the growing season when disease symptoms can be obscured by multiple, late-season foliar diseases, weathering, and insect damage. Bacterium-carrying seed could be harvested, commercially released, and subsequently spread the pathogen over a large geographic area. The specific objective of this research was to develop a rapid and accurate detection method for X. citri pv. malvacearum from cotton plant material.

\section{Materials and Methods}

Bacterial strains and DNA samples. Several strains of the bacterial blight pathogen, $X$. citri pv. malvacearum, representing five known races (race 1, 2, 3, 12, and 18), as well as two additional strains of Xanthomonas were used for DNA extraction (Table 1). The $X$. citri pv. malvacearum strain MSCT1, with an unknown race designation, was isolated from infected cotton leaves collected in Yazoo County, MS in 2011. Pathogenicity of the five races and strain MSCT1was confirmed by vacuum inoculation of cotton seedlings.

Each bacterium was streaked onto nutrient yeast broth (NBY) agar medium and grown for 2 days at $28^{\circ} \mathrm{C}$ (Gross and DeVay 1977). A single colony of each bacterium was recovered and added to liquid NBY medium with continuous shaking $(200 \mathrm{rpm})$ at $28^{\circ} \mathrm{C}$ overnight (approximately $8 \mathrm{~h}$ ). Bacterial cells were harvested from $5 \mathrm{ml}$ of the liquid medium by centrifugation. The resulting bacterial cell pellet was used for DNA extraction. Genomic DNA was extracted with Wizard Genomic DNA Purification Kit (Promega, WI, USA) according to the manufacturer's protocol for gram-negative bacteria. DNA quantity and quality were verified with a Qubit Fluorometer (Invitrogen, NY, USA).

Primer design and PCR modification. A genome comparison method was used to identify specific gene sequences from 19 Xanthomonas strains (Table 2) for the PCR detection of pathogenic Xanthomonas strains using DNASTAR Lasergene software package v12.2 (Wisconsin) (Burland 2000; Zhu et al. 2009). The noncoding region (692300-692504) of the MSCT1 chromosome (GenBank

Table 1. List of Xanthomonas strains or genomic DNA used in the standard and qPCR development

\begin{tabular}{|c|c|c|}
\hline Bacterium & $\begin{array}{l}\text { Isolate } \\
\text { number }\end{array}$ & Source ${ }^{a}$ \\
\hline $\begin{array}{l}\text { Xanthomonas citri pv. malvacearum } \\
\text { MSCT1 }\end{array}$ & MSCT1 & $\begin{array}{r}\text { Showmaker } \\
\text { et al. } 2017\end{array}$ \\
\hline $\begin{array}{l}\text { Xanthomonas citri pv. malvacearum } \\
\text { Race } 1\end{array}$ & Race 1 & P. M. Thaxton \\
\hline $\begin{array}{l}\text { Xanthomonas citri pv. malvacearum } \\
\text { Race } 2\end{array}$ & Race 2 & P. M. Thaxton \\
\hline $\begin{array}{l}\text { Xanthomonas citri pv. malvacearum } \\
\text { Race } 3\end{array}$ & Race 3 & P. M. Thaxton \\
\hline $\begin{array}{l}\text { Xanthomonas citri pv. malvacearum } \\
\text { Race } 12\end{array}$ & Race 12 & P. M. Thaxton \\
\hline $\begin{array}{l}\text { Xanthomonas citri pv. malvacearum } \\
\text { Race } 18\end{array}$ & Race 18 & P. M. Thaxton \\
\hline Xanthomonas citri spp. citri 306 & XАC306 & Nian Wang \\
\hline $\begin{array}{l}\text { Xanthomonas campestris pv. } \\
\text { vesicatoria } 85\end{array}$ & XCV85 & Zhaohui Chu \\
\hline $\begin{array}{l}\text { Xanthomonas campestris pv. campestris } \\
\text { ATCC } 33913\end{array}$ & XCC33913 & Zhaohui Chu \\
\hline
\end{tabular}

a Refers to the acknowledgment for providers' affiliations. 
Accession number: CP017020), which is located downstream of the gene BGK55-3070 encoding a homolog of pyruvate dehydrogenase (Showmaker et al. 2017), was identified as a unique DNA segment via Blastn analysis and used for primer and probe design. One pair of pathovar specific primers (MSCT1-P2F and MSCT1-P2R; Table 3) was designed based on the selected gene sequence. To determine the optimized annealing temperature of the primer pairs, a temperature gradient PCR was carried out using a range of annealing temperatures from 50 to $60^{\circ} \mathrm{C}$.

Strains MSCT1, X. citri pv. malvacearum race 1 to 3,12 , and 18 , and the noncotton pathogen strains $X$. citri spp. citri $306, X$. campestris pv. vesicatoria 85 , and $X$. campestris pv. campestris ATCC 33913 were used for the initial PCR comparison. PCR reactions were carried out in a $25-\mu 1$ reaction volume containing $5.0 \mu \mathrm{l}$ PCR buffer (5×), $2.5 \mu \mathrm{l} \mathrm{MgCl} 2$ (25 mM), $0.75 \mu \mathrm{l}$ dNTPs (10 mM each), $0.75 \mu \mathrm{l}$ each forward and reverse primers $(10 \mu \mathrm{M}), 0.25 \mu \mathrm{l}$ Taq polymerase (5 U $\mu l^{-1}$, Promega Corporation), and $1 \mu \mathrm{l}\left(50 \mathrm{ng} \mu \mathrm{l}^{-1}\right)$ DNA. The PCR reaction was conducted with the following parameters: an initial heating step at $95^{\circ} \mathrm{C}$ for $3 \mathrm{~min}$; followed by 40 cycles of denaturation at $94^{\circ} \mathrm{C}$ for $30 \mathrm{~s}$, annealing at temperature gradient of 50 to $60^{\circ} \mathrm{C}$ for $20 \mathrm{~s}$, and extension at $72^{\circ} \mathrm{C}$ for $20 \mathrm{~s}$; and final extension at $72^{\circ} \mathrm{C}$ for 5 min. Universal $16 \mathrm{~S}$ rDNA primers (27F and 1492R; Eden et al. 1991) were used for DNA quality control. The PCR products were run on $1 \%(\mathrm{w} / \mathrm{v})$ agarose gels in Tris-Acetate-EDTA buffer with ethidium bromide, and photographed using ChemiDoc MP System (BioRad Inc., CA, USA). Xan-MSCT-P1 (Table 3) was synthesized commercially (Eurofins MWG Operon LLC, Louisville, KY) and labeled at the $5^{\prime}$-terminal nucleotide with 6-carboxy-fluorescein (FAM) reporter dye and at the $3^{\prime}$-terminal nucleotide with Black Hole Quencher (BHQ)-1.

DNA templates for standard curves. Strain MSCT1 was cultured in liquid NBY medium and genomic DNA was extracted as described above. A Promega pGEM-T Easy Vector PCR clone system was used to clone the PCR amplicon (the PCR assay was described above with primers MSCT1-P2F and MSCT1-P2R) of MSCT1 to generate the plasmid pMSCT1-p2. Plasmid DNA was isolated using the Qiagen plasmid Miniprep kit. Both plasmid and genomic DNA were used to generate the standard curves to test the sensitivity of the TaqMan Probe. Plasmid and genomic DNA samples were quantified with a Qubit Fluorometer and stored at $-80^{\circ} \mathrm{C}$. PCR was performed based on the plasmid and genomic DNA of MSCT1 as described above. The PCR amplicon was sequenced to confirm the sequence was derived from MSCT1.

Sensitivity and specificity of the qPCR assay. To optimize the qPCR protocol, plasmid pMSCT1-p2 was serially diluted in 10-fold increments over a 7-log scale. The serial dilution with DNA concentrations from $10 \mathrm{ng} \mu \mathrm{l}^{-1}$ to $10^{-6} \mathrm{ng} \mu \mathrm{l}^{-1}$ was used to generate the standard curve to quantify the sensitivity of the primers in triplicate. Primers and reaction conditions were initially screened using SYBR green-based qPCR (Agilent Technologies, Inc.) on an Mx3005P Q-PCR Systems (Agilent Technologies, Inc.). All qPCRs were completed with duplicate technical replicates and no-template negative controls. Following successful reactions for duplicate qPCR runs with no evidence of nonspecific amplification by agarose gel analysis, reaction conditions were optimized for TaqMan based qPCR (TaqMan Master Mixes; Agilent Technologies, Inc.) results.

Final reaction mixtures included $0.5 \mu \mathrm{l}(10 \mu \mathrm{M})$ of each forward and reverse primer, $0.3 \mu \mathrm{l}(10 \mu \mathrm{M})$ TaqMan Black Hole Quencher probe, $10 \mu l(2 \times)$ TaqMan master mix, $1 \mu l$ of sample DNA, and PCR-grade water to a total reaction volume of $20 \mu$ l. The two-step qPCR protocol was performed according to the manual provided within the TaqMan master mix kit (10 min for DNA polymerase activation at $95^{\circ} \mathrm{C}$ followed by 40 cycles of $95^{\circ} \mathrm{C}$ for $30 \mathrm{~s}$ and $60^{\circ} \mathrm{C}$ for $1 \mathrm{~min})$. A standard curve was drawn by plotting the threshold cycle $(\mathrm{Ct})$ against the natural log of the copy number of molecules. A copy number of DNA was calculated with the following equation: copies $\mu l^{-1}=\left[6.022 \times 10^{23}\left(\right.\right.$ copy mol $\left.^{-1}\right) \times$ amount $\left.(\mathrm{g})\right] \times[$ length $(\mathrm{bp}) \times 660$ $\left.\left(\mathrm{g} \mathrm{mol}^{-1} \mathrm{bp}^{-1}\right)\right]^{-1}$ (Cho et al. 2011).

Validation of qPCR methodology with artificially inoculated and naturally infected plant samples. Cotton seedlings (cv. Phytogen 499WRF; Dow AgroSciences, Indianapolis, IN) were grown in an open growth chamber under an 8:16 h light:dark cycle at approximately $23^{\circ} \mathrm{C}$. Seedlings were produced by planting three seeds in one-gallon pots with topsoil in a greenhouse and raised until they were 4 weeks old. Seedlings were subsequently sprayed with an MSCT1 bacterial suspension (washed cells in phosphate buffer, $0.1 \mathrm{M}, \mathrm{pH} 7.0$ ) originating from overnight cultures grown on NBY medium at a concentration of approximately $1,000 \mathrm{CFU} \mathrm{ml} \mathrm{based}^{-1}$ on estimates obtained using a spectrophotometer and a cell density

Table 3. Primers, optimized annealing temperature, and size of product

\begin{tabular}{llcc}
\hline Primer name & \multicolumn{1}{c}{ Primer sequence } & $\begin{array}{c}\text { Tm } \\
\left({ }^{\circ} \mathbf{C}\right)\end{array}$ & $\begin{array}{c}\text { Size of } \\
\text { product }\end{array}$ \\
\hline $\begin{array}{l}\text { Primer } \\
\text { MSCT1-P2F }\end{array}$ & TATTTATTTATCCCACCAGAGG & 47.6 & $205 \mathrm{bp}$ \\
MSCT1-P2R & TCAGAGTATTCAGAGTAAGTGCC & 47.6 & \\
TaqMan Probe & & & \\
Xan-MSCT-P1 & TTGGATCCATCCCCGCCTGAAG & 63.6 & \\
\hline
\end{tabular}

Table 2. Bacterial strains, specific disease caused by each strain, and additional molecular information regarding the strains used for genome comparison

\begin{tabular}{|c|c|c|c|}
\hline Bacterial strain ${ }^{\mathbf{a}}$ & Disease & Sequence method & Source (GenBank) \\
\hline X. albilineans GPE PC73 & Leaf scald of sugarcane & Complete genome & NC013722.1 \\
\hline X. axonopodis pv. citri strain 306 & Citrus canker & Complete genome & NC003919.1 \\
\hline X. axonopodis pv. glycines CFBP 2526 & Bacterial pustule of soybean & Whole genome shotgun & NZCM002268.1 \\
\hline X. axonopodis pv. glycines CFBP 7119 & Bacterial pustule of soybean & Whole genome shotgun & NZCM002264.1 \\
\hline X. axonopodis Xac29-1 & Citrus canker & Complete genome & NC020800.1 \\
\hline X. campestris pv. campestris 8004 & Black rot of cabbage & Complete genome & NC007086.1 \\
\hline X. campestris pv. campestris ATCC 33913 & Black rot of cabbage & Complete genome & NC003902.1 \\
\hline$X$. campestris pv. campestris $\mathrm{CN} 14$ & Black rot of crucifers & Whole genome shotgun & CM001871.1 \\
\hline X. campestris pv. campestris $\mathrm{CN} 15$ & Black rot of crucifers & Whole genome shotgun & CM001890.1 \\
\hline X. campestris pv. campestris $\mathrm{CN} 16$ & Black rot of crucifers & Whole genome shotgun & CM001897.1 \\
\hline X. campestris pv. vesicatoria $85-10$ & Bacterial spot of pepper & Complete genome & NC007508.1 \\
\hline X. citri pv. malvacearum $\mathrm{X} 18$ & Cotton bacterial blight & Whole genome shotgun & CM002136.1 \\
\hline$X$. citri pv. malvacearum $\mathrm{X} 20$ & Cotton bacterial blight & Whole genome shotgun & CM002029.1 \\
\hline X. citri subsp. citri Aw12879 & Citrus canker & Complete genome & NC020815.1 \\
\hline X. oryzae pv. oryzae KACC 10331 & Rice bacterial blight & Complete genome & NC006834.1 \\
\hline X. oryzae pv. oryzae MAFF 311018 & Rice bacterial blight & Complete genome & NC007705.1 \\
\hline X. oryzae pv. oryzae $\mathrm{PXO} 99 \mathrm{~A}$ & Rice bacterial blight & Complete genome & NC010717.1 \\
\hline X. oryzae pv. oryzicola BLS256 & Rice bacterial streak & Complete genome & NC017267.1 \\
\hline X. citri pv. malvacearum $\mathrm{MSCT}^{\mathrm{b}}$ & Cotton bacterial blight & Complete genome & GCA001719145.1 \\
\hline
\end{tabular}

${ }^{a}$ Xanthomonas strains available from the NCBI genome database were used for genome comparison, the strains selected were pathogenic to different hosts.

${ }^{\mathrm{b}} \mathrm{A}$ complete genome sequence of $X$. citri pv. malvacearum MSCT1 was used in this study for sequence comparison and primer design. 
measurement at $\mathrm{OD}_{420}$. Leaves were collected $48 \mathrm{~h}$ postinoculation and DNA was extracted from $1 \mathrm{~g}$ leaf tissue, representing approximately one true leaf, using Wizard Genomic DNA Purification Kit (Promega, WI, USA) according to the manufacturer's protocol for Gram-negative bacteria. The bacterial cell population present on the leaf tissue surface was estimated using a routine serial dilution procedure. Briefly, inoculated leaves were collected and washed with sterile distilled water to remove bacteria. DNA from noninoculated leaves was used as a negative control. The extracted DNA was dissolved in $50 \mu$ l elution buffer and maintained in a $-80^{\circ} \mathrm{C}$ freezer. Experiments were conducted three times.

For verification of the developed qPCR method on cottonseed, a bacterial cell suspension ( $2 \mathrm{ml}$ containing approximately 1,000 cells) was mixed with $10 \mathrm{~g}$ cottonseed (cv. Phytogen 499WRF). Infested seeds were subsequently dried in a laminar flow hood for $1 \mathrm{~h}$ prior to further experimentation, and three replicates were conducted. To recover bacteria from artificially infested seed, the infested seed lot was soaked in $50 \mathrm{ml}$ sterile distilled water for $30 \mathrm{~min}$. Seed without addition of MSCT1 cells was used as a negative control. The liquid supernatant was collected for DNA extraction as described above. The DNA was dissolved in 50- $\mu$ l elution buffer and maintained in a $-80^{\circ} \mathrm{C}$ freezer or used for the qPCR assay. Real-time, quantitative PCR assays were conducted in duplicate for each extract as described above. The qPCR experiment was repeated three times independently.

For the purposes of validating the qPCR protocol with naturally infected cotton plant tissue, 15 cotton leaf and/or and boll samples representing geographically distinct locations and exhibiting characteristic symptoms associated with bacterial blight (e.g., water-soaked lesions on leaves and bolls) were collected from Georgia $(n=9)$, Mississippi $(n=2)$, Tennessee $(n=1)$, and Texas $(n=3)$ during 2016. In addition, healthy asymptomatic plant tissues (three leaf samples and three boll samples) were collected from a cotton field located in Starkville, MS at the R. R. Foil Plant Science Research Center and served as negative controls. Initially, the bacteria were isolated from the plant samples and the bacterial isolates suspected to be $X$. citri pv. malvacearum were used for genomic DNA extraction. Suspected $X$. citri pv. malvacearum was recovered from all infected plant material by culturing the infected plant material on NBY medium, incubating the plates for 2 days under ambient laboratory conditions, and recovering single isolates exhibiting the proper colony morphology and coloration. The X. citri pv. malvacearum culture cells were used as a positive control. Secondly, detection of the pathogen using qPCR directly from cotton samples was conducted. Briefly, the symptomatic lesions were cut from the plant samples for total DNA extraction using Wizard Genomic DNA Purification Kit. The samples $(\approx 0.1 \mathrm{~g}$ each) were macerated in a $1.5 \mathrm{ml}$ microcentrifuge tube containing $100 \mu \mathrm{l}$ of sterile water. After brief centrifugation $(2,000 \mathrm{rpm}$ for $30 \mathrm{~s})$, the supernatants were collected for total DNA extraction as described above. The qPCR was conducted as described above.

In 2017, bacterial blight-infected bolls exhibiting water-soaked lesions were collected from geographically distinct fields. Boll samples were collected from Georgia $(n=3)$, Mississippi $(n=2)$, and Texas $(n$ $=5$ ). Each sample, in this case consisting of a location, was broken down into 10-boll replicates. Replicate samples were ginned separately on a table-top 10-saw gin (Continental Type 10, Continental Gin Company, Lubbock, TX) to separate lint and seed. Fuzzy seed were subsequently delinted using concentrated sulfuric acid $\left(\mathrm{H}_{2} \mathrm{SO}_{4} ; 95 \%\right)$, neutralized with sodium carbonate (soda ash; $\mathrm{Na}_{2} \mathrm{CO}_{3}$ ) as a buffering agent, and dried in a forced air heater $\left(40^{\circ} \mathrm{C}\right)$ for approximately $30 \mathrm{~min}$ or until seeds were dry. Prior to laboratory-based analyses, immature cottonseeds were removed from each replicate sample based on the coloration (all nonblack seed) and size of seed deemed "immature." Therefore, only seeds that were the color and size to be candidates for commercial sale were used in the subsequent analysis. Two different methods were used to confirm the presence of $X$. citri pv. malvacearum from cottonseed: 1) the qPCR methodology, and 2) a culture plate method. To complete the two methods, aliquots of delinted seeds ( 2 to $10 \mathrm{~g}$ ) were ground using a sterilized blender (Waring Blender 7011S, Torrington, CT, USA) for $20 \mathrm{~s}$. One commercial seed lot (cv. Phytogen 499WRF) from which $X$. citri pv. malvacearum was not detected by using the culture-based method was included as a control. Sterile distilled water ( $3 \mathrm{ml} \mathrm{g}^{-1}$ seed) was added to a 50-ml sterile Falcon tube containing the ground seed and vortexed for $5 \mathrm{~s}$ (setting no. 9, Vortex Genie; Scientific Industries, Bohemia, NY). The samples were placed on the lab bench for $20 \mathrm{~min}$ and the supernatant was collected after centrifugation $(300 \times g$ for $5 \mathrm{~min})$ at $25^{\circ} \mathrm{C}$ to remove large seed tissue pieces. An aliquot $(0.5 \mathrm{ml}$ for each sample) of the supernatant was used for bacterial isolation using a culture-based method on NBY agar plates. Bacterial colonies suspected to be $X$. citri pv. malvacearum based on representative colony morphology and color were subsequently purified after 2 days on fresh NBY agar plates and genomic DNA was extracted using Wizard Genomic DNA Purification Kit for sequencing confirmation. The remainder of the supernatant $(\approx 5$ to $10 \mathrm{ml})$ was centrifuged at $4,750 \times g$ for $10 \mathrm{~min}$ to collect bacterial cells, and the resulting pellets were used for genomic DNA extraction. After efficacy comparisons, Powersoil DNA Isolation kit (Mo Bio Laboratories Inc., Carlsbad, CA) was chosen for extraction of genomic DNA as described by the manual with the following modification. A bead beater homogenizer (Mini Beadbeater-8, BioSpec Products, Inc., Bartlesville, OK, USA) was used for breaking cells ( 2 min at the maximum speed). DNA samples were measured by a NanoDrop spectrophotometer (ThermoFisher Scientific, USA) and qPCR was conducted on the StepOnePlus Real-Time PCR System with the Maxima Probe qPCR Mater Mix (Thermo Fisher Scientific). The $\mathrm{qPCR}$ program $\left(50^{\circ} \mathrm{C} 2 \mathrm{~min}\right.$ and then $95^{\circ} \mathrm{C} 10 \mathrm{~min}$ followed by 40 cycles of $95^{\circ} \mathrm{C}$ for $15 \mathrm{~s}$ and $60^{\circ} \mathrm{C}$ for $1 \mathrm{~min}$ ) was used based on the recommendations of the manufacturer. Genomic DNA of MSCT1 was used as a positive control, and two negative controls (sterile distilled water and the genomic DNA from the non- $X$. citri pv. malvacearum infested seed) were included. Three replicates were conducted for each sample. The samples with significantly lower $\mathrm{Ct}$ values than that of the healthy seeds were considered as $X$. citri pv. malvacearum positive.

\section{Results}

Primer design and PCR modification. Using a genome comparison method, the genome sequences of 19 strains of cotton pathogenic and nonpathogenic Xanthomonas strains were compared to identify $X$. citri pv. malvacearum-specific sequences. Sequences that were only identified in cotton pathogenic (i.e., $X$. citri pv. malvacearum) strains were selected and used for primer design. Blast analysis of the candidate gene sequences indicated that the selected sequence was a noncoding region located downstream of the pyruvate dehydrogenase gene (GenBank Accession number: CP017020, Nucleotide sequence: 692300-692504). The PCR primers designed, MSCT1-P2F and MSCT1-P2R, were based on the selected sequence (Table 3).

Gradient PCR analysis showed that the primers MSCT1-P2F and MSCT1-P2R produced the expected amplicon at the annealing temperature $56^{\circ} \mathrm{C}$ without nonspecific amplification from the genomic DNA of strain MSCT1. With the annealing temperature $\left(56^{\circ} \mathrm{C}\right)$, the primers MSCT1-P2F and MSCT1-P2R exclusively amplified the gene region of pathogenic races 1, 2, 3, 12, 18, and MSCT1 (Supplementary Figs. S1 and S2). Using the primer pairs, no cross amplification was observed with the other three non pathovar malvacearum strains XAC306, XCV85, and XCC33913.

Sensitivity and specificity of the qPCR protocol. Standard curves were generated using both the cloned DNA fragment in plasmid pMSCT1-p2 (Fig. 1) and the MSCT1 genomic DNA (Fig. 2). The cut-off $(\mathrm{Ct})$ value for all assays was 35 . The slope of the curves $(k)$ was used to determine the average amplification efficiency $(E)$ with the equation $E=10^{[-1 / k]}$, where $E=2$ corresponds to $100 \%$ efficiency (Ramakers et al. 2003). The amplification efficiency for the standard curve generated by plasmid pMSCT1-p2 (Fig. 1) was $100 \%$. Melting curve analysis using the SRYBR Green method determined that all PCR products shared the same melting temperature (Supplementary Figs. S3 and S4). When genomic DNA of MSCT1 
was used for amplification, the efficiency for the standard curve (Fig. 2 and Supplementary Fig. S5) was 104\%. The assay exhibited a strong linear response $\left(R^{2}=0.998\right.$ and 0.996 , respectively). The detection limit of the reaction was one cloned copy of the $X$. citri pv. malvacearum target gene (Table 4).

The DNA samples of the three nonpathogenic strains XAC306, XCV85, and XCC33913 were used as negative controls to test qPCR specificity. The DNA templates used in the assay were $1 \mathrm{ng}$ in a 20$\mu l$ reaction mixture. For the particular primer set, no cross amplifications were noted for any of the five distinct cotton-pathogenic $X$. citri pv. malvacearum races in the presence of the target pathogen, and no signals were obtained in reactions using DNA of the three nonpathogenic strains.

Validation of qPCR methodology with artificially inoculated and naturally infected plant samples. Using the DNA extracted from the cotton leaf and seed samples, TaqMan based qPCR successfully detected $X$. citri pv. malvacearum $m$ and no PCR amplicon was observed from negative controls. The detection limit was determined to be $10^{2}$ copies from $1 \mathrm{~g}$ of fresh cotton leaf material and 37 copies from $1 \mathrm{~g}$ of seed.

The qPCR method validated successfully the initial diagnosis of the plant samples collected in 2016 (Table 5). All bacteria isolated and suspected to be $X$. citri pv. malvacearum from the naturally infected cotton tissue samples were positive for $X$. citri pv. malvacearum in the qPCR analysis, while the qPCR detections from the healthy leaf and boll samples were $X$. citri pv. malvacearum-negative. In addition, 31 of the 33 seed lots collected from bolls exhibiting symptoms of bacterial blight tested positive for $X$. citri pv. malvacearum using the qPCR analysis (Table 5). In contrast, only 15 of the qPCR-positive seed samples (31 seed lots) were confirmed to carry $X$. citri pv. malvacearum using microbiological media-based isolation methods (Table 5). Based on the morphology of the colonies on NYB and 16S rDNA sequencing, $X$. citri pv. malvacearum was not found on the agar plates from 16 qPCR-positive seed lots or from the two qPCR-negative seed samples.

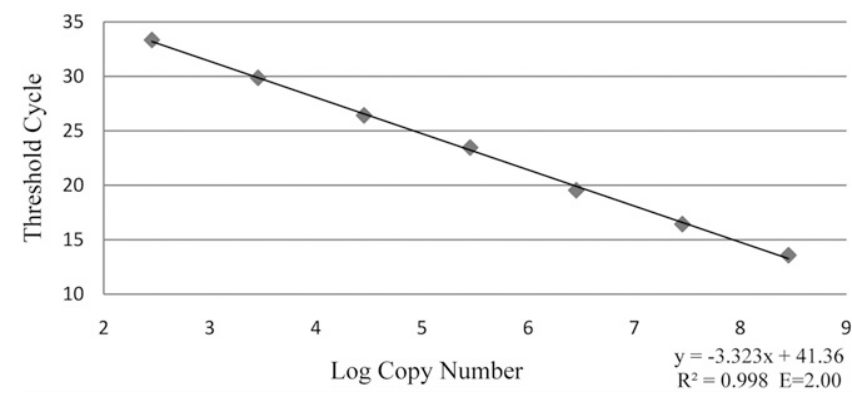

Fig. 1. A standard curve generated using plasmid pMSCT1-p2. A range of DNA concentrations of the plasmid from $1 \mathrm{ng}$ to $10^{-6} \mathrm{ng}$, which were converted to copy numbers as described by Cho et al. (2011). Three replicates were conducted for each concentration.

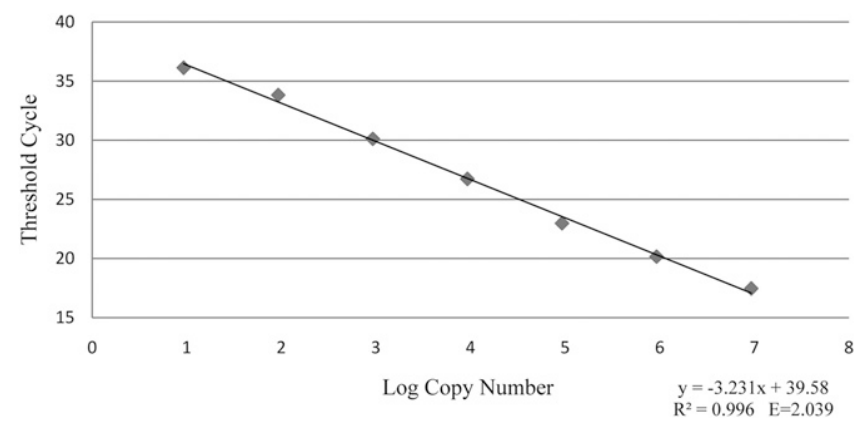

Fig. 2. A standard curve generated using genomic DNA of MSCT1. The standard curve was generated using genomic DNA of MSCT1 in a range from $50 \mathrm{ng}$ to $5 \times$ $10^{-4} \mathrm{ng}$, which were converted to copy numbers as described by Cho et al. (2011). Three replicates were conducted for each concentration.

\section{Discussion}

Since 2011, a resurgence of bacterial blight throughout the U.S. cotton producing regions has resulted in concern regarding the potential presence of $X$. citri pv. malvacearum-infected commercial cotton planting seed (Phillips et al. 2017; Rothrock et al. 2012). As a result of the 2011 outbreak in the U.S. mid-South, a report of $X$. citri pv. malvacearum-infected seed representing multiple cultivars from multiple seed companies was made by Rothrock et al. (2012). Early detection is important for assessing the health of cotton plants, as well as for reducing the likelihood of $X$. citri pv. malvacearum becoming an issue in subsequent seasons as a result of its initial introduction from infected cotton planting seed. Since the early twentieth century, cotton planting seed has been reported as a primary source of bacterial blight in cotton fields (Brinkerhoff and Hunter 1963; Hibbard 1910; Innes 1983; Jenkins 1919; Schnathorst 1964; Thaxton and El-Zik 2001; Verma 1986). Bacterial blight can be destructive even if only one $X$. citri pv. malvacearum-containing seed is planted in a field, as the pathogen can be easily disseminated short distances within a field during favorable environmental conditions, both by natural means, such as blowing rain, and as a result of the agricultural practices involved in farming cotton (Brown 1942; Davis and Sandidge 1977; Tarr 1961). Therefore, having the ability to rapidly detect $X$. citri pv. malvacearum from infected plant material as well as from cotton planting seed is an important tool for limiting the incidence and impact of bacterial blight. Visual detection of bacterial blight on young cotton plants shortly after emergence is difficult. Young cotton plants may exhibit damage from other foliar leaf spot pathogens, or from the widespread use of herbicides that can result in injury to seedling cotton and the foliage of young cotton plants following either pre- or postemergent herbicide applications (Kendig et al. 2007; Kirkpatrick and Rothrock 2001). In addition, where bacterial blight occurs on cotyledon cotton, injury to developing cotton plants can accelerate the spread of bacterial blight from infected plants since $X$. citri pv. malvacearum requires natural openings or wounds for infection (Brinkerhoff 1970; Brinkerhoff and Hunter 1963; Hillocks 1992; Thaxton and El-Zik 2001; Verma 1986).

Development of specific primers and DNA probes from the $16 \mathrm{~S}$ to 23S rDNA spacer region (Sakthivel et al. 2001; Siguier et al. 2006), repeated elements, and siderophore receptor (Zhao et al. 2007) for the purposes of identification and detection have been previously reported for $X$. oryzae pv. oryzae, the causal agent of bacterial blight in rice. A similar strategy was applied for the detection of $X$. arboricola pv. pruni in Prunus sp. (Palacio-Bielsa et al. 2011). However, with regard to the rice qPCR test, it has become evident that the genetic coverage was insufficient to discriminate among the different pathovars of $X$. oryzae. The insertion sequence may undergo periodic extinction in prokaryotic genomes (Cho et al. 2011; Raaijmakers et al. 1994; Siguier et al. 2006). In the current study, we identified some unique regions in the $X$. citri $\mathrm{pv}$. malvacearum genomes using a comparative genomic analysis, which ensured specificity of the selected qPCR primers and probe. Specificity of the primers and probe were important since $X$. citri pv. malvacearum races other than race 18 have previously been reported from the U.S. cotton producing regions (Brinkerhoff 1970; Phillips et al. 2017; Thaxton et al. 1992).

Table 4. Mean cycle threshold $(\mathrm{Ct})$ of 10-fold serial dilutions of MSCT1 cloned DNA and genomic DNA as determined by the TaqMan qPCR

\begin{tabular}{lccccccc}
\hline & \multicolumn{2}{c}{ Plasmid DNA } & & \multicolumn{3}{c}{ Genomic DNA } \\
\cline { 2 - 3 } \cline { 5 - 7 } $\begin{array}{l}\text { Plasmid } \\
\text { copies } \boldsymbol{\mu \mathbf { l } ^ { - 1 }}\end{array}$ & Ct values & $\begin{array}{c}\text { Log } \\
\text { (copy no.) }\end{array}$ & & Weight $\boldsymbol{\mu \mathbf { I } ^ { - 1 }}$ & Ct values & $\begin{array}{c}\text { Log } \\
\text { (copy no.) }\end{array}$ \\
\hline $2.85 \times 10^{8}$ & 13.58 & 8.454 & & $50 \mathrm{ng}$ & 17.46 & 6.967 \\
$2.85 \times 10^{7}$ & 16.43 & 7.454 & & $5 \mathrm{ng}$ & 20.16 & 5.967 \\
$2.85 \times 10^{6}$ & 19.54 & 6.454 & & $500 \mathrm{pg}$ & 22.98 & 4.967 \\
$2.85 \times 10^{5}$ & 23.46 & 5.454 & & $50 \mathrm{pg}$ & 26.73 & 3.967 \\
$2.85 \times 10^{4}$ & 26.42 & 4.454 & & $5 \mathrm{pg}$ & 30.12 & 2.967 \\
$2.85 \times 10^{3}$ & 29.87 & 3.454 & & $500 \mathrm{fg}$ & 33.82 & 1.967 \\
$2.85 \times 10^{2}$ & 33.35 & 2.454 & & $50 \mathrm{fg}$ & 36.13 & 0.967 \\
\hline
\end{tabular}


Previously, Umesha et al. (2010) reported the detection of X. citri pv. malvacearum from cottonseed using morphological, biochemical, and molecular tests developed with ITS primers. However, the specificity of the primers was limited due to limited information regarding the sequences of the pathogenic strains. Recently our research team completed genome sequencing of the local $X$. citri pv. malvacearum strain MSCT1 (Showmaker et al. 2017), which made it possible to identify pathovar-specific genetic loci based on genomewide sequence comparison (Burland 2000). In the current study, TaqMan qPCR primers and probe were designed from a noncoding region and the primer set only produced an amplicon under the conditions described above from the $X$. citri pv. malvacearum strains pathogenic to cotton, but not from nonpathogenic Xanthomas isolates on cotton. Moreover, the primers based on the selected sequence were specific to the strains of cotton-pathogenic $X$. citri pv. malvacearum included in the analysis (races 1, 2, 3, 12, 18, and MSCT1). In addition, when the primers were applied to strains of the bacterium not reported to be pathogenic to cotton (XAC306, XCV85, and XCC33913) no PCR amplicons were obtained.

The sensitivity threshold of $10^{2}$ copies from $1 \mathrm{~g}$ fresh cotton leaf material; and 37 copies from $1 \mathrm{~g}$ of artificially infected cotton seed samples for the Xanthomonas TaqMan qPCR assay was equal to or better than those obtained from previously reported assays for other phytopathogenic bacteria (Dreo et al. 2007; Palacio-Bielsa et al. 2011; Sakthivel et al. 2001; Zhao et al. 2007). The assay we developed surpasses the sensitivity levels reported previously for the conventional PCR method (Hartung et al. 1993). The differences in detection limit between the $X$. citri pv. malvacearum DNA isolated from pure bacterial cultures and DNA isolated from plant tissue may be due to inhibitors present within cotton plant tissues, especially interference from cotton DNA. Extraction of high-quality genomic DNA from cotton plant tissue is difficult because of high concentrations of polysaccharides, phenolic compounds, oxidizable quinones, and additional interfering substances (Demeke and Jenkins 2010; Paterson et al. 1993). In addition, some of the compounds in cotton plant tissues can serve as PCR inhibitors, especially to qPCR (Baeumler et al. 2006). The presence of inhibitors in genomic cotton DNA could interfere with the PCR amplification efficiency and result in reduced detection efficiencies compared with those achieved from DNA isolated from bacterial cultures. In the current study, bacterial isolates from naturally infected field samples exhibiting classical bacterial blight symptoms were confirmed to be $X$. citri pv. malvacearum using the qPCR protocol. The isolation-based microbiological method did not recover the pathogen from the qPCR positive samples, which may result from rich bacterial endophytes and lack of selective media for $X$. citri pv. malvacearum. Diverse bacterial endophytes have previously been recovered from crops including cotton (McInroy and Kloepper 1995). We also noted that cotton seeds grown in different geographical regions exhibited different endophytic bacterial compositions (S. Lu and T. W. Allen, unpublished). On the other hand, the qPCR approach may potentially result in false positive responses due to the numerous uncharacterized bacteria present in cottonseed and other tissues. Therefore, additional research may be necessary to reduce the likelihood of false positives occurring by increasing our understanding and awareness of the known and unknown bacteria that occur on and within cotton plant tissues. However, avoiding false positives may be difficult since the bacterial communities contained within individual seed lots collected from

Table 5. Field collected cotton plant tissue samples from 2016 originating in Georgia, Mississippi, Tennessee, and Texas and 2017 bacterial blight infected bolls originating from Georgia, Mississippi, and Texas used to validate the qPCR methodology and compare with the previous microbiological media methods employed for the detection of the bacterial blight pathogen, Xanthomonas citri pv. malvacearum, from infected plant samples

\begin{tabular}{|c|c|c|c|c|c|c|c|c|}
\hline State & Sample ID & County & Cultivar ${ }^{a}$ & $\begin{array}{l}\text { Bacterial blight } \\
\text { response }^{\mathbf{b}}\end{array}$ & $\begin{array}{l}\text { Bacterial blight } \\
\text { symptoms }\end{array}$ & $\begin{array}{c}\text { Plant } \\
\text { material }\end{array}$ & qPCR result & $\begin{array}{c}\text { Result of } \\
\text { microbiological media }^{\mathrm{d}}\end{array}$ \\
\hline Georgia & 16-GA-1 & Ben Hill & DPL 1555 B2RF (1) & Susceptible & $\mathrm{Y}$ & Leaf & Positive (1) & Positive (1) \\
\hline Georgia & 16-GA-2 & Ben Hill & DPL 1555 B2RF (1) & Susceptible & $\mathrm{Y}$ & Boll & Positive (1) & Positive (1) \\
\hline Georgia & 16-GA-3 & Ben Hill & DPL 1555 B2RF (1) & Susceptible & $\mathrm{Y}$ & Leaf & Positive (1) & Positive (1) \\
\hline Georgia & 16-GA-4 & Ben Hill & DPL 1555 B2RF (1) & Susceptible & $\mathrm{Y}$ & Boll & Positive (1) & Positive (1) \\
\hline Georgia & 16-GA-5 & Ben Hill & PHY 333 WRF (1) & Susceptible & $\mathrm{Y}$ & Leaf & Positive (1) & Positive (1) \\
\hline Georgia & 16-GA-6 & Ben Hill & PHY 333 WRF (1) & Susceptible & $\mathrm{Y}$ & Boll & Positive (1) & Positive (1) \\
\hline Georgia & 16-GA-7 & Seminole & DPL 1538 B2XF (1) & Susceptible & $\mathrm{Y}$ & Leaf/boll & Positive (1) & Positive (1) \\
\hline Georgia & 16-GA-8 & Bainbridge & PHY 333 WRF (1) & Susceptible & $\mathrm{Y}$ & Leaf/boll & Positive (1) & Positive (1) \\
\hline Georgia & 16-GA-9 & Bainbridge & PHY 333 WRF (1) & Susceptible & $\mathrm{Y}$ & Leaf/boll & Positive (1) & Positive (1) \\
\hline Mississippi & 16-MS-1 & Washington & PHY 499 WRF (1) & Susceptible & $\mathrm{Y}$ & Leaf & Positive (1) & Positive (1) \\
\hline Mississippi & 16-MS-2 & Washington & PHY 333 WRF (1) & Susceptible & $\mathrm{Y}$ & Leaf & Positive (1) & Positive (1) \\
\hline Tennessee & $16-\mathrm{TN}-1$ & Carroll & NG 3406 B2XF (1) & Susceptible & $\mathrm{Y}$ & Boll & Positive (1) & Positive (1) \\
\hline Texas & 16-TX-1 & Dawson & PHY 499 WRF (1) & Susceptible & $\mathrm{Y}$ & Leaf & Positive (1) & Positive (1) \\
\hline Texas & 16-TX-2 & Hale & NG 3406 B2XF (1) & Susceptible & $\mathrm{Y}$ & Leaf & Positive (1) & Positive (1) \\
\hline Texas & $16-\mathrm{TX}-3$ & Hale & NG 3517 B2XF (1) & Mostly susceptible & $\mathrm{Y}$ & Leaf & Positive (1) & Positive (1) \\
\hline Georgia & 17-GA-1 & Appling & DPL 1747 NRB2XF (7) & Susceptible & $\mathrm{Y}$ & Black seed & Positive (7) & Positive (4) \\
\hline Georgia & 17-GA-2 & Irwin & DPL 1646 B2XF (3) & Partially resistant & $\mathrm{Y}$ & Black seed & Positive (2) & Positive (0) \\
\hline Georgia & 17-GA-3 & Tift & DPL 1646 B2XF (4) & Partially resistant & $\mathrm{Y}$ & Black seed & Positive (3) & Positive (2) \\
\hline Mississippi & 17-MS-1 & Washington & PHY 499 WRF (4) & Susceptible & $\mathrm{Y}$ & Black seed & Positive (4) & Positive (1) \\
\hline Mississippi & 17-MS-2 & Washington & PHY 499 WRF (5) & Susceptible & $\mathrm{Y}$ & Black seed & Positive (5) & Positive (0) \\
\hline Texas & 17-TX-1-T & Dawson & NG 3406 B2XF (3) & Susceptible & $\mathrm{Y}$ & Black seed & Positive (3) & Positive (3) \\
\hline Texas & 17-TX-2-T & Dawson & NG 3406 B2XF (3) & Susceptible & $\mathrm{Y}$ & Black seed & Positive (3) & Positive (3) \\
\hline Texas & 17-TX-3-J & Dawson & PHY 499 WRF (1) & Susceptible & $\mathrm{Y}$ & Black seed & Positive (1) & Positive (1) \\
\hline Texas & $17-\mathrm{TX}-4-\mathrm{J}$ & Dawson & NG 3406 B2XF (1) & Susceptible & $\mathrm{Y}$ & Black seed & Positive (1) & Positive (0) \\
\hline Texas & 17-TX-5-J & Dawson & NG 3406 B2XF (1) & Susceptible & $\mathrm{Y}$ & Black seed & Positive (1) & Positive (0) \\
\hline Texas & 17-TX-6-J & Dawson & NG 3406 B2XF (1) & Susceptible & $\mathrm{Y}$ & Black seed & Positive (1) & Positive (1) \\
\hline
\end{tabular}

${ }^{a}$ Abbreviations for specific cotton cultivars are as follows: DPL $=$ DeltaPine, PHY = Phytogen, and NG = NexGen. Numbers after cultivars indicate the number of replicate seed samples obtained from each location based on a 10 boll sample exhibiting water-soaked lesions associated with bacterial blight.

${ }^{b}$ Response of cotton varieties to bacterial blight (race 18) are based on information as provided in Kemerait et al. (2017). A susceptible response is based on $>90 \%$ incidence in inoculated field trials, mostly susceptible is based on 60 to $80 \%$ incidence, partially resistant is based on 10 to $25 \%$ incidence, and a resistant response is based on $<10 \%$ incidence in inoculated field trials.

${ }^{\mathrm{c}}$ In instances where black seed was the main variable considered for testing, bolls attributed to the particular variety exhibited symptoms associated with bacterial blight (e.g., water-soaked lesions on bolls that penetrated the carpal wall).

${ }^{\mathrm{d}}$ Observations following the microbiological media methods were based on the colony morphology and resulting molecular analysis of those isolates believed to be $X$. citri pv. malvacearum. 
different geographic locations may in fact be quite diverse (unpublished data). While differences in the fungal endophytic community in both space and time have previously been reported (Ek-Ramos et al. 2013), this has not been a topic considered in the scientific literature for bacterial communities in cultivated cotton.

Even though bacterial blight has been well documented to arise as a result of seedborne $X$. citri pv. malvacearum, there is still some conjecture as to whether or not the organism survives the acid-delinting process on the outside of the seed coat or if the organism survives within embryonic seed tissues (Alexander et al. 2012; Archibald 1927; Bain 1939; Chester 1938; Rolfs 1915; Schnathorst 1968). Previous reports suggest that the greatest percentage of the bacterium is present on seed lint, and this remains one of the main reasons for commercial acid-delinting as a seedborne disease management practice (Gregory et al. 1999). In addition, acid-delinting is performed so the seed coat can be more evenly coated with seed treatment chemicals and to increase the flowability of seed through modern planting equipment that rely on vacuum systems (Alexander et al. 2012). However, acid-delinting, although one of the preferred forms of bacterial blight management, is not fool proof. In the current study, lint was removed from seed with sulfuric acid and "immature" seed was excluded for bacterial isolation or qPCR detection to provide a situation similar to commercial seed production practices. However, $X$. citri pv. malvacearum-positive detection rates were still high ( $>45 \%$ for microbiological media isolation techniques and $>93 \%$ for qPCR) and suggest that even if $X$. citri pv. malvacearum does not survive on the outside of the seed coat, that it more likely survives within the embryo, which is not affected by acid-delinting.

Previous research results suggested that $X$. citri pv. malvacearum can live on cotton plants that do not exhibit bacterial blight symptoms (Davis and Sandidge 1977; Stoughton 1930). Lack of symptom expression could result from a prolonged nonconducive environment following germination of infected seed. Where bacterial blightsusceptible cultivars are produced for cotton planting seed, and certification relies on field scouting to determine the presence of the disease, such determinations are difficult, and the bacterium could enter the seed production pipeline and increase the likelihood of bacterial blight being introduced during the subsequent season. Moreover, the disease can occur in cotton plants that do not exhibit symptoms on bolls, but still harbor $X$. citri pv. malvacearum in infected seed due to the systemic nature of the infection within the plant (Davis and Sandidge 1977; Stoughton 1930). All infected bolls collected during 2017 were observed to exhibit a moderate level of bacterial blight infection as evidenced by the presence of multiple water-soaked lesions on the boll and direct penetration of the pathogen into the carpal wall. Boll and subsequent seed infection was even documented in one variety that has been previously reported to be partially resistant. Therefore, it is strongly suggested that strict scouting practices should be used for detecting the bacterium in field situations where bacterial blight-susceptible cultivars are produced for the purpose of seed production. In addition, it is our professional opinion that fields containing bolls exhibiting bacterial blight symptoms on cotton bolls regardless of the published reaction of the cultivar should be excluded from seed production to limit the spread of the disease. Even though the current research considered the role of cotton exhibiting bacterial blight symptoms, the potential for cottonseed originating from bacterial blight-resistant varieties serving as a source of inoculum should be investigated.

In conclusion, this study demonstrates that the primers and probe set developed are highly specific for some of the more commonly observed $X$. citri pv. malvacearum races from the United States previously reported to be pathogenic to cotton. The main objective of this research was to create a rapid detection method and reduce the time required to positively confirm the presence of $X$. citri pv. malvacearum from cotton plant material. As compared with time-consuming culture-based methods, the TaqMan qPCR assay is reliable and efficient, and it has the potential to be used both as a diagnostic tool to confirm the presence of bacterial blight from cotton plant tissue as well as be used for quality control in cotton seed production systems.

\section{Acknowledgments}

We thank N. Wang (Univ. of Florida) and Z. H. Chu (Shandong Agric. Univ.) for providing genomic DNA samples of the Xanthomonas bacteria. The authors also thank W. Briggs, H. Y. Kelly (Univ. of Tennessee), B. Phillips, J. Story, J. Woodward (Texas A\&M Univ.), and T. Wheeler (Texas A\&M Univ.) for supplying infected cotton plant material to validate methods. Additional thanks are extended to S. M. Baird (Miss. State Univ.) for technical assistance and W. J. Mansour (Miss. State Univ.) and T. H. Wilkerson (Miss. State Univ.) for field sample collection and ginning cotton boll samples. We thank P. M. Thaxton for providing strains of $X$. citri pv. malvacearum for comparison. Lastly, we thank K. Jordan and S. Stetina (USDA-ARS, Stoneville, MS) for help with acid-delinting cottonseed samples.

\section{Literature Cited}

AbdelRahim, K. A. A., Al-Arfaj, A. A., Mashaly, A. M. A., and Rudolph, K. 2013 Plasmids in races of Xanthomonas axonopodis pv. malvacearum (Xam), the causal agent of bacterial blight of cotton. Afr. J. Microbiol. Res. 7:807-813.

Abdo-Hasan, M., Khalil, H., Debis, B., and MirAli, N. 2008. Molecular characterization of Syrian races of Xanthomonas axonopodis pv. malvacearum. J. Plant Pathol. 90:431-439.

Ah-You, N., Gagnevin, L., Grimont, P. A., Brisse, S., Nesme, X., Chiroleu, F., Bui Thi Ngoc, L., Jouen, E., Lefeuvre, P., Verniere, C., and Pruvost, O. 2009. Polyphasic characterization of xanthomonads pathogenic to members of the Anacardiaceae and their relatedness to species of Xanthomonas. Int. J. Syst. Evol. Microbiol. 59:306-318.

Alexander, A. S., Woodward, J. E., Boman, R. K., Wheeler, T. A., and Hopper, N. W. 2012. Effect of the Easiflo cottonseed processing method on recovery of Xanthomonas axonopodis pv. malvacearum. Tex. J. Agric. Nat. Resour. 25:13-23.

Allen, S. J., and West, K.-L. D. 1991. Predominance of race 18 of Xanthomonas campestris pv. malvacearum on cotton in Australia. Plant Dis. 75:43-44.

Archibald, R. G. 1927. Black arm disease of cotton with special reference to the existence of the causal organism B. malvacearum within the seed. Soil Sci. 23:5-12.

Atkinson, G. F. 1891. The black rust of cotton. Coop. Ext. Serv., Alabama Agricultural Experiment Station Bulletin 27. University of Alabama, Tuscaloosa, AL.

Baeumler, S., Wulff, D., Tagliani, L., and Song, P. 2006. A real-time quantitative PCR detection method specific to Widestrike transgenic cotton (Event 281-24236/3006-210-23). J. Agric. Food Chem. 54:6527-6534.

Bain, D. C. 1939. Effect of sulphuric-acid treatment on fungi and bacteria present on cotton seed from diseased bolls. Phytopathology 29:879-884.

Baldwin, C. H., Jr., and Wrather, A. J. 1973. Identification of the existing races of Xanthomonas malvacearum occurring throughout the Mississippi River Delta Vol. 1, Page 29 in: Proc. Beltwide Cotton Prod. Conf. National Cotton Council of America, Phoenix, AZ.

Brinkerhoff, L. A. 1970. Variation in Xanthomonas malvacearum and its relation to control. Annu. Rev. Phytopathol. 8:85-110.

Brinkerhoff, L. A., and Fink, G. B. 1964. Survival and infectivity of Xanthomonas malvacearum in cotton plant debris and soil. Phytopathology 54:1198-1201.

Brinkerhoff, L. A., and Hunter, R. E. 1963. Internally infected seed as a source of inoculums for the primary cycle of bacterial blight of cotton. Phytopathology 53:1397-1401

Brown, J. G. 1942. Wind dissemination of angular leaf spot of cotton. Phytopathology 32:81-90.

Brunings, A. M., and Gabriel, D. W. 2003. Xanthomonas citri: Breaking the surface. Mol. Plant Pathol. 4:141-157.

Burland, T. G. 2000. DNASTAR's Lasergene sequence analysis software. Pages 71-91 in: Bioinformatics Methods and Protocols. Humana Press, Totowa, NJ.

Cherry, J. P., and Leffler, H. R. 1984. Seed. Pages 511-569 in: Cotton. R. J. Kohel and C. F. Lewis, eds. ASA Inc., CSA Inc., and SSA Inc. Publishers, Madison, WI.

Chester, K. S. 1938. Gravity grading, a method for reducing seed-borne disease in cotton. Phytopathology 28:745-749.

Cho, M. S., Kang, M. J., Kim, C. K., Seol, Y.-J., Hahn, J. H., Park, S. C., Hwang, D. J., Ahn, T.-Y., Park, D. H., and Lim, C. K. 2011. Sensitive and specific detection of Xanthomonas oryzae pv. oryzae by real-time bio-PCR using pathovar-specific primers based on an $r h s$ family gene. Plant Dis. 95:589-594.

Davis, R. G., and Sandidge, T. L.,Jr. 1977. Epidemiology of bacterial blight of cotton. Miss. Agric. Exp. Stn. Bull. 88.

De Feyter, R., Yang, Y., and Gabriel, D. W. 1993. Gene-for-genes interactions between cotton $\mathrm{R}$ genes and Xanthomonas campestris pv. malvacearum avr genes.Mol. Plant-Microbe Interact. 6:225-237.

Delouche, J. C. 1986. Harvest and post-harvest factors affecting the quality of cotton planting seed and seed quality evaluation. Pages 483-518 in: Cotton Physiology: The cotton foundation reference book series. J. R. Mauney and J. McD. Stewart, eds. The Cotton Foundation, Memphis, TN

Demeke, T., and Jenkins, G. R. 2010. Influence of DNA extraction methods, PCR inhibitors and quantification methods on real-time PCR assay of biotechnologyderived traits. Anal. Bioanal. Chem. 396:1977-1990.

Dreo, T., Gruden, K., Manceau, C., Janse, J. D., and Ravnikar, M. 2007 Development of a real time PCR based method for detection of Xylophilus ampelinus. Plant Pathol. 56:9-16. 
Eden, P. A., Schmidt, T. M., Blakemore, R. P., and Pace, N. R. 1991. Phylogenetic analysis of Aquaspirillum magnetotacticum using polymerase chain reactionamplified 16S rRNA-specific DNA. Int. J. Syst. Evol. Microbiol. 41:324325.

Ek-Ramos, M. J., Zhou, W., Valencia, C. U., Antwi, J. B., Kalns, L. L., Morgan, G. D., Kerns, D. L., and Sword, G. A. 2013. Spatial and temporal variation in fungal endophyte communities from cultivated cotton (Gossypium hirsutum). PLoS One 8:e66049.

Gitaitis, R., and Walcott, R. 2008. The epidemiology and management of seedborne bacterial diseases. Annu. Rev. Phytopathol. 45:371-397.

Graham, J. H., Gottwald, T. R., Cubero, J., and Achor, D. S. 2004. Xanthomonas axonopodis pv. citri: Factors affecting successful eradication of citrus canker. Mol. Plant Pathol. 5:1-15.

Gregory, S. R., Hernandez, E., and Savoy, B. R. 1999. Cotton seed processing. Pages 793-823 in: Cotton: Origin, History, Technology, and Production. C. W. Smith and J. T. Cothren, eds. Texas A\&M University, College Station, TX.

Gross, D. C., and DeVay, J. E. 1977. Production and purification of syringomycin, a phytotoxin produced by Pseudomonas syringae. Physiol. Plant Pathol. 11: 13-28.

Hartung, J., Daniel, J.-F., and Pruvost, O. 1993. Detection of Xanthomonas campestris pv. citri by the polymerase chain reaction method. Appl. Environ. Microbiol. 59:1143-1148.

Heintz, C. E. 1997. Methods for identifying viable organisms associated with cotton, the cotton plant, and cotton dust. Pages 43-46 in: Cotton and Microorganisms. J. J. Fischer and L. Domelsmith, eds. United States Department of Agriculture, Agricultural Research Service, ARS-138.

Heintz, C. E., and Akinwunmi, O. O. 1997. The gram-positive bacterial flora of cotton. Pages 21-33 in: Cotton and Microorganisms. J. J. Fischer and L. Domelsmith, eds. United States Department of Agriculture, Agricultural Research Service, ARS-138.

Hibbard, R. P. 1910. Cotton disease in Mississippi. Miss. Agric. Exp. Stn. Bull. 140.

Higgins, C. F., Hiles, I. D., Salmond, G. P., Gill, D. R., Downie, J. A., Evans, I. J., Holland, I. B., Gray, L., Buckel, S. D., Bell, A. W., and Hermodson, M. 1986. A family of related ATP-binding subunits coupled to many distinct biological processes in bacteria. Nature 323:448-450.

Hillocks, R. J. 1992. Bacterial blight. Pages 39-85 in: Cotton Diseases. R. J. Hillocks, ed. CAB International, Wallingford, Oxon.

Hunter, R. E., and Brinkerhoff, L. A. 1964. Longevity of Xanthomonas malvacearum on and in cotton seed. Phytopathology 54:617.

Hunter, R. E., Brinkerhoff, L. A., and Bird, L. S. 1968. The development of a set of upland cotton lines for differentiating races of Xanthomonas malvacearum. Phytopathology 58:830-832.

Hussain, T. 1984. Prevalence and distribution of Xanthomonas campestris pv. malvacearum races in Pakistan and their reaction to different cotton lines. Trop. Pest Manage. 30:159-162.

Innes, N. 1983. Bacterial blight of cotton. Biol. Rev. 58:157-176.

Jalloul, A., Sayegh, M., Champion, A., and Nicole, M. 2015. Bacterial blight of cotton. Phytopathol. Mediterr. 54:3-20.

Jenkins, E. W. 1919. Cotton and some of its disease and insects. Fla. Agric. Exp. Stn. Bull., 15.

Kemerait, B., Allen, T., Lu, S., Rothrock, C., Faske, T., Woodward, J., Wheeler, T., Isakeit, T., Bart, R., Phillips, A., Lawrence, K., Hagan, A., Price, P., Mehl, H., Dufault, N., Kelly, H., and Nichols, R. 2017. Identification and Management of Bacterial Blight of Cotton. Cotton Incorporated Bulletin, Cotton Incorporated, Cary, NC.

Kendig, J. A., Nichols, R. L., and Ohmes, G. A. 2007. Tolerance of cotton (Gossypium hirsutum) seedlings to preemergence and postemergence herbicides with four modes of action. Online. Plant Health Prog. 8:4.

King, C. J., and Brinkerhoff, L. A. 1949. The dissemination of Xanthomonas malvacearum by irrigation water. Phytopathology 39:88-90.

Kirkpatrick, T. L., and Rothrock, C. S., eds. 2001. Compendium of Cotton Diseases, 2nd Ed. American Phytopathological Society, St. Paul, MN.

Lee, B.-M., Park, Y.-J., Park, D.-S., Kang, H.-W., Kim, J.-G., Song, E.-S., Park, I.-C., Yoon, U.-H., Hahn, J.-H., and Koo, B.-S. 2005. The genome sequence of Xanthomonas oryzae pathovar oryzae KACC10331, the bacterial blight pathogen of rice. Nucleic Acids Res. 33:577-586.

Massey, R. E. 1929. Blackarm disease of cotton: The development of Pseudomonas malvacearum E. F. Smith, within the cotton plant. Emp. Cotton Grow. Rev. 6:124-153.

Massey, R. E. 1930. Studies on blackarm disease of cotton. 1. Emp. Cotton Grow. Rev. 7:181-195.

McInroy, J. A., and Kloepper, J. W. 1995. Population dynamics of endophytic bacteria in field-grown sweet corn and cotton. Can. J. Microbiol. 41:895-901.

Mehta, Y. R., Bomfeti, C., and Bolognini, V. 2005. A semi-selective agar medium to detect the presence of Xanthomonas axonopodis pv. malvacearum in naturally infected cotton seed. Fitopatol. Bras. 30:489-496.

Meng, X. Q., Umesh, K. C., Davis, R. M., and Gilbertson, R. L. 2004. Development of PCR based assays for detecting Xanthomonas campestris pv. carotae, the carrot bacterial leaf blight pathogen, from different substrates. Plant Dis. 88:1226-1234.
Palacio-Bielsa, A., Cubero, J., Cambra, M. A., Collados, R., Berruete, I. M., and López, M. M. 2011. Development of an efficient real-time quantitative PCR protocol for detection of Xanthomonas arboricola pv. pruni in Prunus species. Appl. Environ. Microbiol. 77:89-97.

Paterson, A. H., Brubaker, C. L., and Wendel, J. F. 1993. A rapid method for extraction of cotton (Gossypium spp.) genomic DNA suitable for RFLP or PCR analysis. Plant Mol. Biol. Report. 11:122-127.

Phillips, A. Z., Berry, J. C., Wilson, M. C., Vijayaraghavan, A., Burke, J., Bunn, J. I., Allen, T. W., Wheeler, T., and Bart, R. S. 2017. Genomics-enabled analysis of the emergent disease cotton bacterial blight. PLoS Genet. 13:e1007003.

Raaijmakers, J. M., Bitter, W., Punte, H., Bakker, P., Weisbeek, P. J., and Schippers, B. 1994. Siderophore receptor PupA as a marker to monitor wildtype Pseudomonas putida WCS358 in natural environments. Appl. Environ. Microbiol. 60:1184-1190.

Ramakers, C., Ruijter, J. M., Deprez, R. H. L., and Moorman, A. F. M. 2003 Assumption-free analysis of quantitative real-time polymerase chain reaction (PCR) data. Neurosci. Lett. 339:62-66.

Razaghi, A., Hasanzadeh, N., and Ghasemi, A. 2012. Characterization of Xanthomonas citri subsp. malvacearum strains in Iran. Afr. J. Microbiol. Res. 6:1165-1170.

Rolfs, F. M. 1915. Angular leaf spot of cotton. South Carolina Agric. Exp. Stn Bull. 184.

Rothrock, C. S., Kirkpatrick, T. L., Barber, T., Coker, C. M., and Smith, S. E. 2012 The resurgence of bacterial blight of cotton in Arkansas. Page 299 in: Proc. Beltwide Cotton Prod. Conf. National Cotton Council of America, Memphis, TN.

Sakthivel, N., Mortensen, C., and Mathur, S. 2001. Detection of Xanthomonas oryzae pv. oryzae in artificially inoculated and naturally infected rice seeds and plants by molecular techniques. Appl. Microbiol. Biotechnol. 56:435-441.

Schaad, N. W., Postnikova, E., Lacy, G., Sechler, A., Agarkova, I. V., Stromberg, P. E., Stromberg, V. K., and Vidaver, A. M. 2006. Emended classification of Xanthomonad pathogens on citrus. Syst. Appl. Microbiol. 29:690-695.

Schnathorst, W. C. 1964. Longevity of Xanthomonas malvacearum in dried cotton plants and its significance in dissemination of the pathogen on seed. Phytopathology 54:1009-1011.

Schnathorst, W. C. 1968. Introduction of Xanthomonas malvacearum into California in acid-delinted and fumigated cotton seed. Plant Dis. 52:981-982.

Showmaker, K. C., Arick, M. A., II, Hsu, C.-Y., Martin, B. E., Wang, X., Jia, J., Wubben, M. J., Nichols, R. L., Allen, T. W., Peterson, D. G., and Lu, S. 2017. Complete genome sequence of the cotton bacterial blight pathogen Xanthomonas citri pv. malvacearum strain MSCT1. Stand. Genomic Sci. 11: 88

Siguier, P., Filée, J., and Chandler, M. 2006. Insertion sequences in prokaryotic genomes. Curr. Opin. Microbiol. 9:526-531.

Starr, M. P. 1981. The genus Xanthomonas. Pages 742-763 in: The prokaryotes. M. P. Starr, H. Stop, H. G. Trüper, A. Balows, and H. G. Schlegel, eds. Springer Verlag, Berlin

Stoughton, R. 1930. Angular leaf-spot disease of cotton. Nature 125:350-351.

Tarr, S. A. J. 1961. Seed treatment against blackarm diseases of cotton in the Sudan. V. Results with seed carrying light and moderate infection. Emp. Cotton Grow. Rev. 38:30-35.

Thaxton, P. M., and El-Zik, K. M. 2001. Bacterial blight. Pages 34-35 in: Compendium of Cotton Diseases, 2nd Ed. T. L. Kirkpatrick and C. S Rothrock, eds. American Phytopathological Society, St. Paul, MN.

Thaxton, P. M., El-Zik, K. M., and Kirkpatrick, R. K. 1992. Races of Xanthomonas campestris pv. malvacearum in cotton under natural infestation in Texas. Pages 181-182 in: Proc. Beltwide Cotton Prod. Conf. National Cotton Council of America, Memphis, TN.

Umesha, S., Chythra, R., Kavitha, R., Niranjana, S., Prakash, H., and Mortensen, C. 2010. Molecular detection of Xanthomonas citri subsp malvacearum in cotton seeds. Res. J. Biotechnol. 5:20-26.

Vauterin, L., Hoste, B., Kersters, K., and Swings, J. 1995. Reclassification of Xanthomonas. Int. J. Syst. Bacteriol. 45:472-489.

Vauterin, L., Rademaker, J., and Swings, J. 2000. Synopsis on the taxonomy of the genus Xanthomonas. Phytopathology 90:677-682.

Verma, J. P. 1986. Bacterial Blight of Cotton. CRC Press, Boca Raton, FL.

Verma, J. P., Singh, R. P., and Nayak, M. L. 1975. Laboratory evaluation of chemicals against Xanthomonas malvacearum, the incitant of bacterial blight of cotton. Indian Phytopathol. 28:171-174.

Yang, P., Vauterin, L., Vancanneyt, M., Swings, J., and Kersters, K. 1993. Application of fatty acid methyl esters for the taxonomic xnalysis of the genus Xanthomonas. Syst. Appl. Microbiol. 16:47-71.

Young, J. M., Park, D. C., Shearman, H. M., and Fargier, E. 2008. A multilocus sequence analysis of the genus Xanthomonas. Syst. Appl. Microbiol. 31: 366-377

Zhao, W.-J., Zhu, S., Liao, X.-L., Chen, H.-Y., and Tan, T.-W. 2007. Detection of Xanthomonas oryzae pv. oryzae in seeds using a specific TaqMan probe. Mol. Biotechnol. 35:119-127.

Zhu, D. S., Zhou, M., Fan, Y. L., and Shi, X. M. 2009. Identification of new target sequences for PCR detection of Vibrio parahaemolyticus by genome comparison. J. Rapid Methods Aut. Microbiol. 17:67-79. 